Abstracta Iranica Abstracta Iranica

Revue bibliographique pour le domaine irano-aryen

Volume 25 | 2004

Comptes rendus des publications de 2002

\title{
«Un temple du feu sassanide découverte à Mele Hairam (Turkménistan méridional) ». St. Ir. 31, 2, (2002), pp. 215-230.
}

\section{Rémy Boucharlat}

\section{(2) OpenEdition}

1 Journals

\section{Édition électronique}

URL : https://journals.openedition.org/abstractairanica/4364

DOI : 10.4000/abstractairanica.4364

ISSN : 1961-960X

Éditeur :

CNRS (UMR 7528 Mondes iraniens et indiens), Éditions de l'IFRI

\section{Édition imprimée}

Date de publication : 15 mai 2004

ISSN : 0240-8910

Référence électronique

Rémy Boucharlat, « « Un temple du feu sassanide découverte à Mele Hairam (Turkménistan méridional) ». St. Ir. 31, 2, (2002), pp. 215-230. », Abstracta Iranica [En ligne], Volume 25 | 2004, document 104, mis en ligne le 15 mars 2006, consulté le 28 juin 2022. URL : http://

journals.openedition.org/abstractairanica/4364 ; DOI : https://doi.org/10.4000/abstractairanica.4364

Ce document a été généré automatiquement le 29 septembre 2020.

Tous droits réservés 


\title{
« Un temple du feu sassanide découverte à Mele Hairam
}

\section{(Turkménistan méridional) ». St. Ir. 31, 2, (2002), pp. 215-230.}

\author{
Rémy Boucharlat
}

Après la découverte du temple (?) atypique de Bandian, Dargaz, dans le nord du Khorassan (St. Ir. 27,2, (1998)) celui de Mele Hiram dans une région proche s'inscrit dans une très petite série de documents archéologiques (Takht-i Solaiman, Tureng Tepe). Celui-ci apporte des informations précieuses. La mission polonaise y a en effet mis au jour des installations bien conservées, autels sur socle, tables et foyers, décors. L'A. reconnaît dans cet ensemble de quatre salles, un ayvan, incomplètement fouillé, décoré de peintures murales et dont le centre est occupé par un massif de terre recouvert de stucs à motifs floraux, un espace presque carré au centre duquel se trouve l'autel, très probablement en forme de sablier, et, au-delà, une petite chambre qui résiste à l'interprétation, et sur un côté, la salle de conservation du feu. Par comparaison des stucs à ceux de Bandian ( $5^{\mathrm{e}} \mathrm{s}$.) et de sites mésopotamiens, l'A. date le monument entre le $5^{\mathrm{e}}$ et le $7^{\mathrm{e}} \mathrm{s}$.

\section{INDEX}

Thèmes : 3.2.3. Séleucides, Parthes et Sassanides 
AUTEURS

RÉMY BOUCHARLAT

CNRS - Lyon 